\title{
Pemanfaatan Media Youtube Dakwah Ustadz Adi Hidayat dalam Pengembangan Materi Fikih Madrasah Ibtidaiyah
}

\author{
Guntur Cahyono \\ Institut Agama Islam Negeri (IAIN) Salatiga \\ e-mail : guntur_elfikri@yahoo.com
}

\begin{abstract}
Social media are beneficial not only to communicate interpersonally but also to preach and educate people. One of these media is Youtube that can be applied in developing learning materials by capitalizing online preaching of Islam teachers (ustadz) uploaded in this medium. This research gives description on how Youtube is useful as part of learning material development. In this research, the description reveals the facts that teachers employ not only text books or student work books (LKS) in material development but also online videos. Youtube videos of ustadzAdiHidayat can be used to develop Islamic principal (Fiqh) learning materials in Islamic elementary schools by downloading those videos. Teachers are required to be savvy in operating internet media in learning material development for teaching and learning process.
\end{abstract}

Keywords: Media, Youtube, Fiqh, Learning 


\section{Pendahuluan}

Dewasa ini, kehidupan manusia berkembang begitu pesat. Seiring dengan perkembangan zaman pula, manusia dihadapkan dengan situasi dan kondisi di mana mereka harus saling berinteraksi dengan manusia lainnya, karena pada hakikatnya manusia adalah makhluk sosial. Proses interaksi antar manusia ini disebut dengan komunikasi. Secara umum, komunikasi merupakan "pusat" atau "inti” dari kehidupan manusia, karena komunikasi yang efektif dapat membantu kita meningkatkan relasi dengan orang-orang lain dalam hubungan personal, kelompok, organisasi, komunitas maupun masyarakat (Liliweri, $2015: 4$ )

Media sosial akhir-akhir ini menempati posisi penting dalam penyampaian informasi kepada masyarakat. Peran ini berjalan begitu masif dengan perkembangan alat komunikasi seperti android dalam kurun kurang dari satu dasawarsa terakhir. Media sosial membawa informasi begitu cepat mengirim informasi terus menerus dalam hitungan detik. Informasi yang berasal dari jarak yang begitu jauh akan mudah didapatkan. Kondisi ini dimanfaatkan oleh individu, kelompok serta korporasi baik secara positif ataupun negatif untuk menyampaikan berbagai hal dalam hal ini termasuk pula pembelajaran di kelas.

Teknologi informasi dan komunikasi yang berkembang sangat pesat mengakibatkan beragamnya teknologi informasi komunikasi yang muncul dan ditawarkan ditengahtengah masyarakat. Inovasi teknologi dan konvergensi berbagai media melaju pesat sejalan dengan permintaan dan kebutuhanyang semakin tinggi. Seiring perkembangan zaman yang menuntut segala sesuatu serba cepat dan akurat, maka sekarang ini media massa online yang memegang peranan penting dan kedudukan tertinggi dibandingkan dengan media massa lainnya dalam menyampaikan informasi atau pesan yang tersebar luas di masyarakat (Arfiko, $2018: 2$ ).

Masifnya peran media sosial di dunia pendidikan mengubah perilaku guru dan siswa dalam banyak hal. Cara bersikap menghadapi derasnya informasi baik itu posting konten yang bersifat negatif atau positif bahkan benar atau salah (hoax). Media sosial saat ini sudah menjadi kebutuhan teknologi yang penting bagi semua pengguna manfaatnya. Melalui media sosial itulah dunia pendidikan bisa mengakses berbagai macam situs.

Media sosial menjadi media untuk berinteraksi sosial di dunia maya, sebagai suatu rangkaian terus menerus tanpa henti dibalik komunikasi sosial. Menurut Andreas Kaplan dan Michael Haenlein dalam buku "Users of the world, unite! The challenges and opportunities of social media” (2010) yang dikutip oleh Emawarni (2017 : 3) 
mendefinisikan media sosial sebagai sebuah kelompok aplikasi berbasis internet yang membangun di atas dasar ideolagi dan teknologi web 2.0, dan memungkinkan pencipta dan pertukaran user-Generated content.

Saat teknologi internet dan mobile phone makin maju maka media sosial pun ikut tumbuh dengan pesat. Media sosial dalam bentuk video yang banyak diminati serta mudah mengakses adalah Youtube. Jika facebook, whatsapp dan twitter memerlukan proses pertemanan untuk mengakses maka Youtube tidak memerlukan proses koneksi pertemanan bagi orang yang ingin mengaksesnya.

Menurut Vice President of Engineering Youtube, Cristos Goodrow dalam Kompas Tekno dari thenextweb.com (2/3/2017) yang dikutip Arfiko (2018 : 2), durasi orang menonton video di platform tersebut telah meningkat drastis, totalnya mencapai 1 miliar jam per hari dan memiliki lebih dari satu miliar pengguna, hampir sepertiga dari semua pengguna internet mengakses Youtube setiap harinya meluangkan waktu mereka berjamjam untuk mengakses video di Youtube dan menghasilkan miliar kali penayangan. Motivasi sangat penting bagi proses belajar karena menggerakan organisme, mengarah tindakan, serta memiliki tujuan belajar yang paling berguna bagi kehidupan individu.

Youtube hingga kini menjadi situs video content sharing terbesar di dunia yang telah menguasai $60 \%$ dari jumlah total penikmat video online. Saat ini pengguna Youtube rata-rata telah mengunggah 72 jam video ke situs Youtube setiap menitnya, ini meningkat drastis bila dibandingkan satu tahun lalu yang hanya 48 jam per menitnya. Youtube telah memiliki 4 miliar video dan 800 juta pengguna yang mengakses dari berbagai belahan dunia.

Munculnya media sosial Youtube digemari oleh para pelajar untuk sekedar melihat video atau pun mengunggah video dalam Youtube. Youtube sendiri memiliki banyak manfaat, diantaranya adalah untuk mencari film, melihat musik, video terbaru dan lain sebagainya. Tidak lepas dari Youtube juga memiliki kekurangan misalnya kurang penyaringan antara video yang mencerminkan citra negatif karena itu,banyak siswa pelajar yang menggunakan Youtube untuk melihat video yang tidak layak dilihat salah satunya tidak mencerminkan berkebudaya timur (Marindo, Puntoadi, Sutedja, 2011 : 42).

Pemanfaat layanan Youtube yang begitu banyak menggiring orang untuk banyak memposting kegiatannya agar bisa dinikmati oleh banyak orang. Termasuk dalam hal ini memosting kegiatan pengajian. Fenomena banyaknya pengajian yang direkam kemudian diposting melalui Youtube memungkinkan pengajian itu dilihat oleh orang banyak 
dan dilihat secara berulang-ulang. Youtube memiliki akses yang luas dan terbuka bagi siapapun membagikan videonya.

Pengajian yang memiliki misi dakwah, tentu sangatlah tepat manakala menggunakan fasilitas yang disediakan oleh Youtube. Para penggunanya selain bisa melihat video yang telah diposting. Koneksi internet memungkinkan pula para pengguna mengakses dimanapun selama ditempat tersebut ada akses internet. Perangkat yang digunakanpun lebih fleksibel dan banyak orang memilikinya seperti laptop maupun smartphone. Menurut Chandra (2017 : 407) menyebutkan setahun sejak kelahirannya, pada tahun 2006 youtube. com telah menjadi situs yang bertumbuh dengan cepat. Dengan diunggahnya video baru sebanyak 65.000 dan mencapai 100.000 video hingga bulan Juli 2006 ke situs video Youtube. Rekor tersebut mampu menembus 5 situs terpopuler di situs alexa.com, jauh mengalahkan situs myspace.com. Pada bulan Juni 2006 Situs video Youtube memasuki bidang kerjasama pemasaran dan periklanan dengan NBC.

Dakwah hakikatnya adalah upaya untuk menumbuhkan kecendrungan dan ketertarikan. Menyeru seseorang dalam agama Islam maknanya adalah berupaya untuk menumbuhkan kecendrungan dan ketertarikan pada apa yang diserukan yakni Islam sehinggal dakwah Islam tidak hanya terbatas pada aktivitas lisan, namun mencakup seluruh aktivitas lisan atau perbuatan yang ditujukan dalam rangka menumbuhkan kecendrungan dan ketertarikan pada Islam (Mahmud, $2006: 34$ )

Dalam dakwah Islam tentu pengunggah membidik umat Islam walaupun kemudian umat lain juga bisa mengakses dengan mudah karena sifat media sosial yang terbuka dan bisa diakses siapapun. Selain sebagai kegiatan dakwah video dakwah dari Ustadz Adi Hidayat menjadi fenomena tersendiri di Youtube bisa dijadikan sebagai sumber untuk pengembangan materi pembelajaran. Materi pembelajaran ini adalah mata pelajaran Fikih di Madrasah Ibtidaiyah karena isi pengajian lebih banyak berkaitan dengan hukum Islam. Misalnya tentang tata cara shalat, zakat dan ibadah lainnya.

Pendidikan Fikih merupakan bagian integral dari pendidikan agama, yang bermaterikan tentang kegiatan praktek keagamaan yang dilakukan. Dengan demikan secara bersamaan materi Fikih bisa membentuk kepribadian peserta didik, dan mempengaruhi watak dan perilaku peserta didik. Mata pelajaran Fikih memiliki kontribusi dalam memberikan motivasi kepada peserta didik untuk mempraktekkan nilai-nilai agama dalam kehidupan sehari-hari. Sementara itu dalam kurikulum mata pelajaran Fikih belum mencakup berbagai hal yang dibutuhkan peserta didik. Peran strategis guru dalam konsep 
pembelajaran ini diperlukan kosep kreatif yang bisa memanfaatkan perkembangan teknologi saat ini.

Pada proses pemanfaatan media guru perlu memahami prinsip dan kriteria pemanfaatan media supaya pemanfaatan media berjalan efektif dan efisien. Pemilihan media pembelajaran menurut Nana Sudjana dan Ahmad Rivai (2009 : 82) hendaknya memperhatikan kesesuaian, efektif, mudah didapat, bisa menggunakannya, Tersedia waktu untuk menggunakannya, serta sesuai dengan taraf berpikir peserta didik.

Informasi yang terdapat dalam pembelajaran perlu disampaikan kepada peserta didik dengan upaya kreatif dan mengikuti perkembangan teknologi. Sebagaimana yang telah ditulis Mahnun (2012:27) penggunaan media pada pembelajaran di kelas merupakan satu hal yang tidak bisa diabaikan karena proses belajar di kelas yang dilakukan oleh peserta didik terfokus pada penambahan wawasan dan pengetahuan guna membekali dirinya pada hari ini dan nanti.

Saat ini media berbasis komputer dan internet menjadi media yang mudah dimanfaatkan sesuai dengan perkembangan jaman. Media pengajaran ini meliputi perangkat keras (hardware) dan perangkat lunak (software). Hardware adalah alatalat yang dapat mengantar pesan seperti $L C D$ projector, perangkat komputer radio dan sebagainya. Sedangkan software adalah isi program yang mengandung pesan seperti informasi yang mengandung pesan seperti informasi yang terdapat pada file atau buku dan bahan-bahan cetakan lainnya. Salah satu media untuk mengenalkan pembelajaran adalah melalui Youtobe.

Youtube ini bukan hanya alat bantu pembelajaran di kelas tetapi lebih kepada pemanfaatan konten yang dikembangkan melalui berbagai penjelasan lebih detail tentang materi tertentu yang bisa dipakai guru untuk menyampaikan materi yang tidak hanya terbatas pada kurikulum yang ada. Materi pelajaran bisa dikembangkan sesuai kebutuhan dengan cara mengambil materi pengajian yang telah di share. Adapun manfaat Youtube dalam pengembangan pembelajaran seperti disampaikan oleh Djali (2000: 23-26) sebagai berikut :

Pertama, integrasikan Youtube dengan media lain seperti blog atau materi presentasi, yaitu seorang guru mampu mengembangkan media pembelajaran untuk presentasi baik berbasis offline maupun online. Kedua, mengembangkan komunitas belajar melalui Youtube di mana guru dan siswa terlibat bersama-sama. Ketiga, buat siswa melakukan diskusi online melalui Youtube secara menarik. Keempat, upload konten video dan 
jadikan bahan pembelajaran untuk mobile learning. Kelima, presentasi efektif dan efisien di channel video youtube anda. Keenam, Membantu mengembangkan kemampuan siswa membuat komentar berbentuk catatan di komentar youtube.

\section{Dakwah}

Ada beberapa istilah yang perlu dipahami dengan beberapa arti tentang dakwah. Dalam Ilmu Komunikasi pesan dakwah adalah massage, yaitu simbol-simbol. Dalam literatur berbahasa Arab, pesan dakwah disebut maudu'ad- da'wah. Istilah pesan dakwah dipandang lebih tepat untu menjelaskan, isi dakwah berupa kata, gambar, lukisan dan sebagainya yang diharapkan dapat memberikan pemahaman bahkan perubahan sikap dan perilaku mitra dakwah (Aziz, $2004: 318)$.

Pesan dakwah tidak berbeda dengan pokok-pokok ajaran Islam. Banyak klasifikasi yang diajukan para ulama dalam memetakan Islam. Endang Saifuddin Anshari yang dikutip Aziz (2004 : 332) membagi pokok-pokok ajaran Islam seperti akidah, syariah, dan akhlak. Sedangkan menurut Darmawan (2005 : 35) secara etimologi, kata dakwah berasal dari bahasa Arab yaitu da'a, yad'u, da'watan, yang berarti memanggil, menyeru, mengundang, atau mengajak. Ajak atau seruan ini bisa dilakukan dengan berbagai hal, dimana salah satunya memanfaatkan media sosial. Media sosial disini yaitu media sosial berbasis video Youtube. Dakwah adalah bagian dari proses menyampaikan pengetahuan Islam yang biasa dilakukan dengan membentuk kelompok- kelompok pengajian yang ada di lingkungan masyarakat. Pengajian disini bisa dilakukan dengan membuat kelompokkelompok kecil maupun kelompok besar.

Pada perkembangan ilmu dakwah, tabligh diartikan sebagai bentuk dakwah dengan cara menyampaikan atau menyebar luaskan ajaran Islam melalui media mimbar dan media massa (baik elektronik maupun cetak), dengan sasaran orang banyak atau khalayak. Pada prinsipnya, tabligh bersifat kontinue, artinya kegiatan dakwah yang senantiasa terus menerus harus dilaksanakan dan kaum Muslimin yang memiliki kewajiban untuk terus melaksanakan tabligh sampai akhir hayat (Enjang, 2009 : 56)

Selama ini kita biasa melihat proses dakwah ataupun pengajian di media televisi. Perkembangan media sosial Youtube memberikan arah baru bagi terciptanya model dakwah yang lain dengan format berbagi link atau video. Pengajian selalma ini secara konvenional membutuhkan ruang dan waktu tertentu, maka dengan Youtube bisa 
memungkin jamaah untuk mendapatkan konten pengajian kapanpun dan dimanapun. Jamaah juga bisa memilih ustadz atau kyai yang disukai serta tema yang sesuai dengan kebutuhan. Youtube memiliki kemampuan menyebarkan konten dakwah atau pengajian keseluruh dunia dan bisa dilihat oleh banyak kalangan sesuai dengan kebutuhan masingmasing. Youtube juga mampu memberikan akses kepada penggunan dengan cara mendownload ataupun melihat secara on line.

\section{Materi Fikih}

Mata Pelajaran Fikih adalah salah satu mata pelajaran Pendidikan Agama Islam yang diarahkan untuk menyiapkan peserta didik untuk mengenal, memahami, menghayati terutama dalam ibadah sehari-hari, yang kemudian menjadi dasar pedoman hidup (way of life) melalui kegiatan bimbingan, pengajaran, latihan, penggunaan pengalaman dan pembiasaan (Badan Standar Nasional Pendidikan, 2007: 328). Dengan demikian pembelajaran Fikih tidak hanya dengan mendengarkan apa yang diuraikan oleh guru mata pelajaran Fikih tetapi siswa melalui kegiatan bimbingan, latihan serta pembiasaan dalam kegiatan pembelajaran.

Sedangakang mata pelajar fikih di Madrasah Ibtidaiyah merupakan salah satu mata pelajaran PAI yang mempelajari tentang fikih ibadah terutama menyangkut pengenalan dan pemahaman tentang pelaksaan rukun Islam dan pembiasaan dalam kehidupan seharihari. Fikih muamalah mengenalkan peserta didik berkaitan dengan ketentuan tentang makan dan minuman halal dan haram, khitan, qurban, jual beli dan pinjam meminjam.

Pembelajaran Fikih bermuatan materi yang relevan terhadap kehidupan. Hasil pembelajaran dapat diaplikasikan sebagai ibadah keseharian. Keputusan Menteri Agama No. 165 Tahun 2014 tentang Kurikulum 2013 mata pelajaran PAI dan Bahasa Arab di Madrasah terdapat tujuan mata pelajaran Fikih pada Madrasah Ibtidaiyah adalah mengetahui dan memahami pokok hukum Islam dan siswa dapat melaksanakan dan mengamalkan ketentuan hukum Islam dengan benar, sehingga dapat menumbuhkan ketaatan dalam menjalankan hukum Islam, disiplin dan tanggung jawab sosial yang tinggi dalam kehidupan pribadi maupun sosialnya.

Keberhasilan pembelajaran secara keseluruhan sangat tergantung pada keberhasilan guru merancang materi pembelajaran. Materi Pembelajaran pada hakekatnya merupakan bagian tak terpisahkan dari Silabus, yakni perencanaan, prediksi dan proyeksi tentang apa yang akan dilakukan pada saat Kegiatan Pembelajaran. Secara garis besar dapat 
dikemukakan bahwa Materi pembelajaran (instructional materials) adalah pengetahuan, keterampilan, dan sikap yang harus dikuasai peserta didik dalam rangka memenuhi standar kompetensi yang ditetapkan.

Materi pembelajaran menempati posisi yang sangat penting dari keseluruhan kurikulum, yang harus dipersiapkan agar pelaksanaan pembelajaran dapat mencapai sasaran. Sasaran tersebut harus sesuai dengan Standar Kompetensi dan Kompetensi Dasar yang harus dicapai oleh peserta didik. Artinya, materi yang ditentukan untuk kegiatan pembelajaran hendaknya materi yang benar-benar menunjang tercapainya standar kompetensi dan kompetensi dasar, serta tercapainya indikator yang diwujudkan dalam bentuk bahan ajar.

Bahan ajar adalah sebuah persoalan pokok yang tidak bisa dikesimpangkan dalam satu kesatuan pembahansan yang utuh tentang cara pembuatan bahan ajar. Ada penjelasan lain, bahan ajar adalah seperangkat materi baik tertulis maupun tidak tertulis yang disusun secara sistematis dengan menampilkan sosok utuh kompetensi yang akan dikuasai peserta didik untuk membantu guru dan peserta didik dalam melaksanakan proses pembelajaran. Apabila guru dapat memanfaatkan bahan ajar secara baik, maka guru dapat berbagi peran dengan bahan ajar. Dengan begitu, peran guru akan lebih mengarah sebagai manajer pembelajaran (Andi Prastowo, 2014 : 16).

Pengembangan materi fikih pada Madrasah Ibtidaiyah ditujukan bukan pada pembelajaran tekstual satu arah melainkan sesuai dengan konsep pembelajaran pada kurikulum 2013 yaitu dengan pembelajaran interaktif serta pemanfaatan multimedia. Konten video yang mendukung pembelajaran audio visual terhadap peserta didik diharapkan mendukung secara optimal dalam proses pembelajaran.

Menurut Bruce Will (1980) sebagaimana yang dikutip oleh Wina Sanjaya (2009 : 218), ada tiga prinsip yang dijalankan dalam proses pembelajaran, yaitu : Pertama, proses pembelajaran adalah membentuk kreasi lingkungan yang dapat membentuk atau mengubah struktur kognitif siswa. Tujuan pengaturan lingkungan ini dimaksudkan untuk menyediakan pengelaman belajar yang memberi latihan-latihan penggunaan fakta-fakta. Kedua, berhubungan dengan tipe-tipe pengetahuan yang harus dipelajari. Ada tiga tipe pengetahuan masing- masing memerlukan situasi yang berbeda dalam mempelajarinya. Pengetahuan tersebuat adalah pengetahuan fisik, pengetahuan sosial dan pengetahuan logika. 


\section{Guntur Cahyono 71 \\ Pemanfaatan Media Youtube Dakwah Ustadz Adi Hidayat dalam Pengembangan Materi Fikih \\ Madrasah Ibtidaiyah}

Prinsip-prinsip yang harus dijadikan dasar dalam mengembangkan materi pembelajaran, menurut Gafur (2005 : 17) adalah kesesuaian (relevansi), keajegan (konsistensi), dan kecukupan (adequacy).

Dalam pengembangan materi pembelajaran guru harus mampu mengidentifikasi dan mempertimbangkan hal-hal berikut:

1. Potensi peserta didik; meliputi potensi intelektual, emosional, spiritual, sosial, dan potensi vokasional.

2. Relevansi dengan karakteristik daerah; jika peserta didik dan sekolah berlokasi bertempat di daerah pantai, maka pengembangan materi pembelajaran diupayakan agar selaras dengan kondisi masyarakat pantai

3. Tingkat perkembangan fisik, intelektual, emosional, sosial, dan spritual peserta didik;

4. Kebermanfaatan bagi peserta didik; pengembangan materi pembelajaran diupayakan agar manfaatnya dapat dirasakan peserta didik dalam waktu yang relatif singkat setelah suatu materi pembelajaran tuntas dilaksanakan.

5. Struktur keilmuan; mengembangkan materi pembelajaran sosiologi harus didasarkan pada struktur keilmuan sosiologi.

6. Aktualitas, kedalaman, dan keluasan materi pembelajaran; mengembangkan materi pembelajaran hendaknya selalu mempertimbangkan potensi peserta didik, tingkat perkembangan peserta didik, kebermanfaatan bagi peserta didik, alokasi waktu, dan perkembangan peradaban dunia

7. Relevansi dengan kebutuhan peserta didik dan tuntutan lingkungan;

8. Alokasi waktu.

Dalam pengembangan materi fikih pada Madrasah Ibtidaiyah dengan media Youtube yang berisikan dakwah Ustadz Adi Hidayat, Lc.,M.A ini tidak hanya peserta didik yang aktif mengaplikasikan teori yang disampaikan. Guru pun turut mempraktikkan serta memberikan pemahaman tambahahan kepada peserta didik. Dengan begitu, pembelajaran interaktif dapat berlangsung dikelas. Tanggung jawab peserta didik saat dalam masyarakat adalah dengan mempraktikkan teori yang disampaikan sebagai ibadah keseharian sehingga sesuai dengan tujuan dan fungsi pembelajaran Fikih pada Madrasah Ibtidaiyah.

| Volume. 4, No. 1, Januari-Juni 2019 


\section{Metode Penelitian}

Penelitian ini menggunakan jenis penelitian kualitatif, hal ini dikarenakan data yang akan dianalisis berupa data yang diperoleh dengan cara pendekatan kualitatif. Penelitian ini merupakan penelitian lapangan yang bersifat kualitatif. Kualitatif adalah metode penelitian dimana peneliti adalah sebagai instrumen kunci dalam sebuah penelitian. Disebut juga metode penelitian kualitatif kerena data yang dihasilkan merupakan analisis yang bersifat kualitatif atau kualitas dan bukan bersifat kuantitas atau jumlah. Data yang dihasilkanpun dalam penelitian kualitatif ini tidak memerlukan analisis statistika (perhitungan) seperti yang ada dalam penelitian kuantitatif (Sugiyono, 2013: 14).

Dalam penelitian ini peneliti mendiskripsikan data dengan kata-kata, kalimat dan mengurai bukan dengan angka. Moleong (2006 : 2) menyatakan bahwa penelitian kualitatif mengedepankan data dengan berlandaskan pada pengungkapan apa-apa yang diungkapkan oleh responden dari data yang dikumpulkan berupa kata-kata, gambar, dan bukan angka-angka. Adapun cara yang digunakan dalam penelitian ini adalah melalui pengumpulan data dan informasi secara objektif untuk menghasilkan informasi yang valid, terkini dan relevan dari fokus penelitian yang berkaitan dengan tentang pengembangan materi untuk mata pelajaran fikih di madrasah ibtidaiyah dari video pengajian di Youtube dari Ustadz Adi Hidayat.

\section{Hasil Penelitian}

\section{Dakwah Ustadz Adi Hidayat di Youtube}

Perjalanan dakwah ustadz Adi Hidayat tidak lepas dengan keberadaan Akhyar TV. Diawali dari siaran di Akhyar TV melalui beberapa channel tayangan baik live streaming atau Youtube. Walaupun kemudian tayangan dakwah Ustadz Adi Hidayat tersebar oleh berbagai Youtuber yang diambil dari sumber aslinya atau Youtuber merekam sendiri kegiatan dakwah ustadz Adi Hidayat. Tayangan Akhyar TV, dapat diakses dimanapun \& kapanpun asalkan gadget telah terhubung dengan internet. Cukup masuk ke www.akhyar. tv untuk menampilkan halaman utama.

Akhyar TV adalah chanel resmi yang dipakai Ustadz Adi Hidayat untuk melakukan siaran pengajian dan kegiatan dakwahnya. Baik lewat lewat live streaming maupun pengajian yang sudah dunggah di channel Youtube. Ini menjadi siaran resmi yang dijadikan sumber siaran utama pengajian Ustadz Adi Hidayat. Dalam prosesnya ada beberapa kisah yang melatar belakangi mengapa Ustadz Adi Hidayat perlu menggunakan media sosial Youtube untuk membagikan kagiatan dakwahnya. 
\begin{tabular}{r|r} 
Guntur Cahyono & 73 \\
Pemanfaatan Media Youtube Dakwah Ustadz Adi Hidayat dalam Pengembangan Materi Fikih & Madrasah Ibtidaiyah
\end{tabular}

\section{Pengembangan Materi Ajar Fikih di MI}

Pemilihan materi ajar dipilih seoptimal mungkin untuk membantu peserta didik dalam mencapai standar kompetensi dan kompetensi dasar. Hal-hal yang perlu diperhatikan berkenaan dengan pemilihan materi pembelajaran adalah jenis, cakupan, urutan dan perlakuan (treatment) terhadap materi pembelajaran tersebut. Agar guru dapat membuat persiapan yang berdaya guna dan berhasil guna, dituntut memahami berbagai aspek yang berkaitan dengan pengembangan materi pembelajaran, baik berkaitan dengan hakikat, fungsi, prinsip, maupun prosedur pengembangan materi serta mengukur efektivitas persiapan tersebut.

Menurut Pannen yang dikutip oleh Bahri (2015 : 97), materi pembelajaran adalah adalah bahan-bahan atau materi pembelajaran yang disusun secara sistematis yang digunakan oleh pengajar dan pembelajar dalam proses pembelajaran. Bahan Ajar itu unik dan sepesifik. Unik artinya, bahan ajar itu hanya dapat digunakan untuk audiens tertentu dalam suatu proses pembelajaran tertentu. Sepesifik artinya isi materi pembelajaran tersebut dirancang sedemikian rupa hanya untuk mencapai tujuan tertentu dan sistematika cara penyampaiannya pun disesuaikan dengan karakteristik mata pelajaran dan karakteristik siswa yang menggunakannya.

Jenis-jenis materi pembelajaran dalam http://ramdanus73.blogspot.com /2015/05/ jenis-jenis-materi-pembelajaran.html (diakses 26 September 2018) dapat diklasifikasi sebagai berikut :

a. Fakta

Fakta adalah segala hal yang berwujud kenyataan dan kebenaran, meliputi namanama objek, peristiwa sejarah, lambang, nama tempat, nama orang, nama bagian atau komponen suatu benda, dan sebagainya.

b. Konsep

Konsep adalah segala yang berwujud pengertian-pengertian baru yang bisa timbul sebagai hasil pemikiran, meliputi definisi, pengertian, ciri khusus, hakikat, dan inti/isi.

c. Prinsip

Prinsip adalah berupa hal-hal utama, pokok, dan memiliki posisi terpenting, meliputi dalil, rumus, adagium, postulat, paradigma, teorema, serta hubungan antar konsep yang menggambarkan implikasi sebab akibat.

d. Prosedur

Prosedur merupakan langkah-langkah sistematis atau berurutan dalam mengerjakan suatu aktivitas dan kronologi suatu sistem. 


\section{e. Sikap atau Nilai}

Sikap atau Nilai merupakan hasil belajar aspek sikap, misalnya nilai kejujuran, kasih sayang, tolong- menolong, semangat dan minat belajar, dan bekerja.

Para guru di kecamatan Gatak biasanya memilih pengembangan materi ajar dari buku LKS atau buku-buku Fikih ataupun dari mendengarkan kegiatan pengajian. Sumber ini tentu saja sangatlah terbatas dan relatif sulit untuk didapatkan. Dengan perkembangan teknologi informasi seperti sekarang ini internet menjadi rujukan pengembangan materi yang bisa dilakukan. Pada pengembangan materi Fikih dipilihlah dakwah ustadz Adi Hidayat yang tersebar di Youtube sebagai sumber pengembangan materi.

Dakwah dan model dakwah ustadz Adi Hidayat seperti sedang mengajar memudahkan guru memiliki gambaran pengajaran setelah adanya pengembangan materi. Sementara itu ustadz Adi Hidayat lebih sering mengkaji masalah-masalah hukum atau fikih menjadikan alasan mengapa dakwah ustadz Adi Hidayat bisa dijadikan sumber pengembangan materi.

Secara umum guru sudah memiliki perangkat yaitu smart phone untuk mengakses internet untuk mendapatkan materi. Sedangkan madrasah belum bisa memfasilitasi secara penuh untuk kegiatan harian yang berhubungan dengan internet seperti perlengakapan wifi atau mifi. Guru lebih sering menggunakan fasilitas pribadi dalam proses pengerjaan pengembangan materi untuk menunjang pembelajaran dikelas.

Peran kepala sekolah menjadi sangat penting bagi kegiatan pengembangan materi yang dilakukan guru. Pemberian kemudahan dan kebebasan dalam mengembangan materi ajar yang dilakukan guru memudahkan guru untuk meningkatkan kwalitas pembelajaran di era teknologi informasi ini. Kepala madrasah bermaksud membuat kebijakan sehingga madrasah terhubung dengan fasilitas internet sehingga bisa dilakukan guru. Namun ada beberapa madrasah yang belum mampu mewujudkannya.

Dalam pengembangan materi fikih seperti dijelaskankan diatas telah dirumuskan bahan pengembangan materi oleh guru kelas untuk pembelajaran fikih dalam RPP sebagai berikut :

1. Judul Video Youtube : Fiqih Zakat._Zakat Mal. Zakat Emas \& Zakat Tabungan. Ustadz Adi Hidayat sumber link : https://www.youtube.com/watch?v=W5bHVPx2qs

2. Judul Video Youtube : Harta tidak sampai 40 juta, Wajib Zakat ?? | Ustad Adi Hidayat,LC,MA sumber link : https://www.youtube.com/watch?v=DLgw_LY2H6Q 3. Judul Video Youtube : Hukum Membayar Zakat Fitrah dengan UANG! Ceramah 
Guntur Cahyono

Terbaru Ustadz Adi Hidayat, Lc., MA sumber link : https://www.youtube.com/ watch? $=1$ iLD2s3J2eA

4. Judul Video Youtube : 8 Golongan yang Berhak Menerima Zakat - Ustadz Adi Hidayat Lc MA sumber link : https://www.youtube.com/watch?v=dqO3QDR4um0

5. Judul Video Youtube : Hukum Melebihkan Zakat 2,5 \% - Ustadz Adi Hidayat Lc MA sumber link : https://www.youtube.com/watch?v=8QJgcHgzKpo

6. Judul Video Youtube : Seputar Rukun Islam (Kajian Full) - Ustadz Adi Hidayat sumber link : https://www.youtube.com/watch?v=SaA7nGnMxt0

7. Judul Video Youtube : Pembahasan Seputar Rukun Islam - Ust. Adi Hidayat, Lc. MA sumber link : https://www.youtube.com/watch?v=ptRv6fixxXk

Darisatumateripembelajarangurubisamemanfaatkan paling tidak duasampaidengan lima link Youtube pengajian Adi Hidayat sebagai bagian dari proses pengembangan materi dan disusun dalam rencana pelaksanaan pembelajaran. Link di atas dimanfaatkan dengan membuat analisis kebutuhan dalam proses pembelajaran dengan mempertimbangkan prinsip relevansi, konsistensi dan kecukupan. Menurut Suprihatiningrum (2013 : 302) untuk mengembangkan materi pembelajaran guru harus memperhatikan potensi siswa, relevansi dengan karakteristik daerah, tingkat perkembangan fisik, intlektual, emosional, sosial, dan spritual siswa, kebermanfaatan bagi siswa, struktur keilmuan, aktualitas, kedalaman, dan keluasan materi pembelajaran, relevansi dengan kebutuhan siswa dan tuntutan lingkungan dan alokasi waktu.

\section{Langkah Download Materi}

Supaya sumber pengembangan meteri bisa ditonton secara off line, maka guru harus mendownload materi. Melihat secara off line bertujuan untuk menghemat penggunaan uota internet selain itu memudahkan proses pencarian karena bisa jadi beberapa dakwah ustadz Adi Hidayat di hapus oleh admin yang mengupload dengan berbagai banyak alasan.

Adapun cara memperoleh materi melalui perangkat laptop maka laptop harus terhubung dengan internet dengan hotspot pribadi dari masing-masing perangkat smartphone guru. Adapun langkah-langkah untuk mendownload adalah sebagai berikut :

1. Buka Google Chrome atau Mozilla Firefox

2. Ketik https://www.youtube.com/ pada bar

3. Ketik di bar Telusur Youtube sesuai dengan tema pembelajaran misalnya ketik : zakat menurut adi hidayat

| Volume. 4, No. 1, Januari - Juni 2019 
4. Klik sesuai dengan kebutuhan dari masing-masing judul yang akan dijadikan materi.

5. Ketik di bar chrome sebagai download secara on line https://id.savefrom.net/

6. Copy link Youtube lalu paste ke bar just insert a link di savefrom.net akan secara otomatis muncul unduh

7. Klik unduh setelah muncul menu unduh klik OK

8. Setelah selesai download, video bisa dilihat secara off line

\section{Kesimpulan}

Dari penelitian yang dilakukan oleh peneliti bisa disimpulkan bahwa Pengembangan materi tidak hanya bersumber pada buku saja tetapi merespon perkembangan teknologi informasi video pengajian atau dakwah Adi Hidayat di Youtube bisa menjadi rujukan ataupun sumber pengembangan materi. Secara akademik ustadz Adi Hidayat memiliki kualifikasi keilmuan dimana kegiatan dakwahnya bisa menjadi sumber pengembangan materi karena banyak mengupas masalah- masalah fikih. Guru awalnya masih menggunakan sumber pengembangan materi berupa buku atau LKS dalam pengembangan materi ajar. Penelitian ini memberikan gambaran bahwa Youtube bisa dijadikan bahan pengembangan materi untuk pembelajaran fikih.

\section{Daftar Pustaka}

Ali Aziz, Moh. 2004. Ilmu Dakwah. Jakarta: Prenadamedia Group

Arfiko, Yori. 2018. Pengaruh Pesan Dakwah Pada Channel Youtube Yufid.TV Terhadap Motivasi Belajar Ilmu Agama Islam. JOM FISIP Vol. 5: Edisi I Januari - Juni 2018 Halaman 1-8

Bahri, Ratni Bt. H., Pengembangan Materi Pembelajaran Membaca Dalam Pembelajaran Bahasa Arab Di Perguruan Tinggi Pada Era Globalisasi Jurnal Manajemen Pendidikan Islam TADBIR Volume 3 Nomor 1 Februari 2015 Halaman 97 - 104

Chandra, Edy. 2017. Youtube, Citra Media Informasi Interaktif Atau Media Penyampaian Aspirasi Pribadi. Jurnal Muara Ilmu Sosial, Humaniora, dan Seni. Vol. 1, No. 2, Oktober 2017: hlm 406-417

Darmawan, Andy. 2005. Ibda'i Bi Nafsika: Tafsir Baru Keilmuwan Dakwah. Yogyakarta: Tiara Wacana

Djali, 2000. Buku Manfaat Youtube untuk Pembelajar. Jakarta: Program Pascasarjana

Gafur, Abdul. 2005. Desain intruksional: langkah sitematis penyusunan pola dasarkegiatan belajar mengajar, Solo: Tingah Serangkai

Liliweri, Alo. 2015. Komunikasi AntarPersonal. Jakarta: Prenadamedia Group

Mahmud, Ahmad. 2011. Dakwah Islam. Bogor: Pustaka Thariqul Izzah 
Marindo, R., Puntoadi, D., \& Sutedja, S. 2011. Menciptakan Penjualan Melalui Social Media. Jakarta: PT Elex Media Komputindo

Menteri Pendidikan Nasional. 2007. Peraturan Menteri Pendidikan Nasional Nomor 16 Tahun 2007 Tentang Kompetensi Guru. Jakarta: Kementerian Pendidikan Nasional

Moleong, Lexy J. 2007. Metodologi Penelitian Kualitatif, Bandung: Penerbit PT Remaja Rosdakarya Offset

Rivai, Ahmad, Nana Sudjana. (2009). Media Pengajaran. Bandung: Sinar Baru Algensindo.

Sadiman et. al. 2006. Media Pendidikan. Bandung: Pustaka Media Sanjaya, Wina. 2009. Kurikulum Dan Pembelajaran. Jakarta : Kencana Prenada Media Group

Sugiyono. 2009. Metode Penelitian Kuantitatif, Kualitatif dan R\&D. Bandung: Alfabeta

Suprihatiningrum, Jamil. 2013. Strategi Pembelajaran Teori dan Aplikasi. Yogyakarta: Arruz Media

Winkel, W. S. 2007. Psikologi Pengajaran. Jakarta : Gramedia Widiasarana Indonesia https://id.wikipedia.org/wiki/YouTube diakses 6 April 2018 http://www.akhyar.tv/profilustadz-adi-hidayat/ diaskses tanggal 24 September 2018

https://news.detik.com/opini/d-3573499/berawal-dari-mimpi-bertemu- rasul-dakwahadi-hidayat-sesak-atensi diakses 23 September 2018

http://ramdanus73.blogspot.com/2015/05/jenis-jenis-materi-pembelajaran diakses tanggal 26 September 2018

Sukarni .2012. Memanfaatkan YouTube Sebagai Media Pembelajaran yang Interaktif, Menarik dan Menyenangkan. Link : http://guraru.org/gurumedia_pembelajaran kan/ diakses 21 September 2018 pada 12:52 WIB

At.titume. 4, No. 1, Januari - Juni 2019 